\title{
Students' Empowerment Through the Drug Prevention Education Program
}

\author{
Zurkurnan* \\ University of Islamic Sciences Malaysia \\ Malaysia \\ zurkurnan.yusoff@gmail.com*
}

\author{
Abd. Halim \\ University of Islamic Sciences Malaysia \\ Malaysia \\ halimhussin@yahoo.com
}

\begin{abstract}
Drug addiction is a social problem that is constantly affecting the student population. Student engagement statistics in drug addiction show an increasing trend of drug abuse. To address this problem, the Ministry of Education Malaysia (MOE) has introduced the Drug Prevention Education Program (DPEP) to help schools plan and implement drug prevention programs in schools. As such, a more interactive approach has been introduced to produce drug-free students through the integrated and comprehensive DPEP program in the areas of management and leadership, curriculum, cocurriculum, and personality development and can build high resilience and physical well-being among students physically, emotionally, mentally and spiritually.
\end{abstract}

Keywords - drug prevention, drug abuse, students, guidance and counseling

\section{INTRODUCTION}

Student empowerment through DPEP including: Social problems in the community; student engagement statistics in drug addiction; Ministry of Education Drug Prevention Education Program (DPEP) by the Ministry of Education Malaysia (MOE); Planning and implementation of DPEP in schools; Assessment and Impact of the DPEP Program; Successes and challenges in program success.

Social symptoms are a problem that is often discussed in today's community. It strikes all society regardless of place. This social problem is a worrying one as it can be a scary tragedy when young people start to get caught up in these symptoms [1]. This problem usually arises from the attitude of adults who build family institutions of fragile values and then produce children in the heat of internal and external heat. Some of the social problems in society are as follows:

1. Drug abuse. Misuse of drugs means the use of drugs in the wrong way especially if their use is affecting the nervous system. Drug abuse is a major problem in the country. The government has to spend a lot of money to solve this problem that has plagued the community.

2. Gangsters. Most cases of gangsters involve serious injury and can result in death, damage to public property, and so on. Cases of gangsterism are the highest percentage of cases involving teenagers.

3. Loitering. Loitering is a time-wasting activity that involves walking around and traveling without any direction.
Usually, it occurs in groups of at least two people. Time slots are not tied to time, either day or night. The group is also open to teenagers on the sidewalks or the elderly in coffee shops. They are more likely to choose hangout as a way to escape the stress of life.

4. Close Proximity. Proximity in Arabic means the act of isolating or isolating (calming the mind with meditation and so on). The second meaning is that both are in a secluded or hidden space between a man and a woman who are not married and not a husband who can be considered an act of disobedience. Close proximity that is meant to be social problems here is by isolating themselves in a quiet place between men and women who are not strangers and can cause slander. It is an act forbidden in Islam. This is because it is the beginning of adultery. The prohibition of adultery is not just the act, but the behavior of the people to him as well.

5. Drink kratom (mitragyna speciosa) water. (known as Ketum in Malaysia) Drinking kratom water, whether small or large, drunk or not is prohibited and is considered guilty because it has been mixed with various substances to create an illusion. But this act is seen as a trivial matter by today's society. This activity is not only harmful to the drinker but also the family and others. A kratom drinker gives a reason for wanting to quit drug addiction and lead a better life without realizing the dangers of kratom.

6. Teenagers Running Away from Home. The problem of children running away from home is closely related to the disadvantages of running a household. Adolescents are easily influenced by their friends outside for fun because when they are at home they are often overwhelmed by the narrow home environment, many siblings or parents. Instead, they ran away because of family poverty, parental strife, film influence, and more.

7. Skanks (Bohsia). Bohsia is a nickname to a girl group and is often associated with symptoms of rheumatism. It can be termed as a troubled teenager out looking for a man who has a motorcycle to get rid of their boredom. Originally their activity was to seduce teen motorcycle riders for fun. They get along with each other for fun and have sex or drink alcohol. Some of them share more than one man to satisfy their desire. 
Table 1. Student Involvement in Drug Abuse in Kelantan Year $2013-2017$

\begin{tabular}{|c|c|c|c|}
\hline Year & Tested & Positive & $\%$ \\
\hline 2013 & 3760 & 120 & 3.2 \\
\hline 2014 & 2474 & 170 & 6.9 \\
\hline 2015 & 3114 & 164 & 5.2 \\
\hline 2016 & 2286 & 123 & 5.3 \\
\hline 2017 & 2766 & 279 & 10 \\
\hline
\end{tabular}

Table 2. Student Involvement in Drug Abuse in Malaysia Year

\begin{tabular}{|c|c|c|c|}
\multicolumn{5}{|c|}{$2013-2017$} \\
\hline Year & Tested & Positive & $\%$ \\
\hline 2013 & 39163 & 720 & 1.8 \\
\hline 2014 & 36838 & 1469 & 3.93 \\
\hline 2015 & 49711 & 1748 & 3.51 \\
\hline 2016 & 35522 & 1411 & 3.8 \\
\hline 2017 & 36664 & 1731 & 5 \\
\hline
\end{tabular}

These statistics show that drug abuse among students is taking place across the country and this data is alarming for teachers, parents, and all citizens concerned about drug-free life. The programs and activities of educators in partnership with the National Anti-Drug Agency (NADA) have been held throughout the year to achieve the goals of the "drugfree school". The main program conducted in schools to achieve this goal is the Drug Prevention Education Program (DPEP).

\section{MINISTRY OF EDUCATION PREVENTION PROGRAM (DPEP) BY THE MINISTRY OF EDUCATION MALAYSIA (MOE)}

On February 28, 1983, the Anti-Drug Cabinet Committee declared "National Enemy Drug". The Ministry of Education of Malaysia has been given the responsibility to design and implement the Drug Prevention Education Program (DPEP) in schools. The main goals of the program are for students, teachers, school staff, and parents.

The problem of widespread drug use today is not only affecting adults but it is contagious for teenagers. This incident is becoming more critical as the production of various types of drugs including the increasing number of counterfeit drugs. This situation keeps our students exposed and at risk. Recognizing this fact, the Ministry of Education

Malaysia is responsible for implementing a systematic and effective Drug Prevention Education Program in schools. The DPEP mission is implemented to set a goal of the drug-free student's through a DPEP program integrated and comprehensive in terms of management and leadership, curriculum, co-curriculum, and personality development. follows:

The objectives of Drug Prevention Education are as

a. Increase the knowledge, understanding, and skills of Drug Prevention Education to students, teachers, and school staff to prevent drug abuse.

b. Establish a high degree of self-esteem among students physically, emotionally, mentally, and spiritually.

c. It enables students to develop positive cultures and behaviors and practice good values. d. Involve and establish a partnership between the school and the public community to prevent drug abuse.

\section{PLANNING AND IMPLEMENTATION OF DPEP \\ IN SCHOOLS} follows:

Proposals for DPEP Planning in schools are as

Table 3. DPEP Plan in Schools

\begin{tabular}{|c|c|c|}
\hline No. & Program & Methods of implementation \\
\hline 1 & $\begin{array}{l}\text { DPEP Committee Member } \\
\text { Meeting }\end{array}$ & $\begin{array}{c}\text { Regular meetings } \\
\text { Supervision and monitoring }\end{array}$ \\
\hline 2 & Staff Development & $\begin{array}{l}\text { Talks / workshops / seminars / } \\
\text { forums / tours }\end{array}$ \\
\hline 3 & $\begin{array}{l}\text { Primary School Drug } \\
\text { Program (PROSIDAR) }\end{array}$ & $\begin{array}{c}\mathrm{R} \& \mathrm{D} \text { is based on a module that has } \\
\text { been distributed to schools during } \\
\text { the CBC }\end{array}$ \\
\hline 4 & $\begin{array}{c}\text { Student Urine Test } \\
\text { (Secondary) }\end{array}$ & Collaboration with NADA \\
\hline 5 & Anti-drug Sunday & $\begin{array}{c}\text { Conducting activities related to } \\
\text { DPEP } \\
\text { Feb } 19 \text { and June } 26 \\
\end{array}$ \\
\hline 6 & $\begin{array}{l}\text { Drug Abuse (School } \\
\text { Assembly) Message }\end{array}$ & Poster / banner / flyers / banner etc. \\
\hline 7 & $\begin{array}{c}\text { DPEP in KSSM } \\
\text { (Secondary School) }\end{array}$ & $\begin{array}{l}\text { R\&D in accordance with KSSM's } \\
\text { PPD book during the CTR }\end{array}$ \\
\hline 8 & $\begin{array}{c}\text { Primary School Vocabulary } \\
\text { Program }\end{array}$ & According to the predefined Module \\
\hline 9 & DPEP talks & $\begin{array}{c}\text { World drug/day rally/school official } \\
\text { event }\end{array}$ \\
\hline 10 & DPEP exhibition & $\begin{array}{c}\text { DPEP week celebrations are on Feb. } \\
19 \text { and June } 26\end{array}$ \\
\hline 11 & $\begin{array}{c}\text { National Badge Scheme } \\
\text { (SLAD) (Secondary } \\
\text { School) }\end{array}$ & Guided by the SLAD Log Book \\
\hline 12 & $\begin{array}{l}\text { Appointment of New } \\
\text { Members and SLAD } \\
\text { General Meeting }\end{array}$ & $\begin{array}{c}\text { Presentation of the Badge and Log } \\
\text { Book }\end{array}$ \\
\hline 13 & $\begin{array}{l}\text { SLAD Camps (Secondary } \\
\text { Schools) }\end{array}$ & Offer a camp for SLAD members \\
\hline 14 & Drawing a DPEP Poster & DPEP carnival \\
\hline 15 & Poetry Writing & DPEP carnival \\
\hline 16 & Poetry Reciting & DPEP carnival \\
\hline 17 & $\begin{array}{l}\text { Anti-drugs Dikir Barat ( } \\
\text { Kelantan Culture Choir) }\end{array}$ & DPEP carnival \\
\hline 18 & $\begin{array}{l}\text { Anti-drugs Boria ( Penang } \\
\text { Culture Choir) }\end{array}$ & DPEP carnival \\
\hline 19 & $\begin{array}{l}\text { Anti-drugs Nasyid ( } \\
\text { Religious Choir) } \\
\end{array}$ & DPEP carnival \\
\hline 20 & Scrapbook & $\begin{array}{c}\text { School, District, State, and National } \\
\text { level. }\end{array}$ \\
\hline 21 & $\begin{array}{l}\text { Personal and Interpersonal } \\
\text { Skills }\end{array}$ & $\begin{array}{c}\text { Workshops / Seminars / Group } \\
\text { Counseling / Courses / Forums / } \\
\text { Colleges }\end{array}$ \\
\hline 22 & DPEP counseling & $\begin{array}{c}\text { Individual Counseling / Group } \\
\text { Counseling / Family Counseling }\end{array}$ \\
\hline 23 & $\begin{array}{c}\text { Student Intervention } \\
\text { Program (PIP) } \\
\end{array}$ & $\begin{array}{l}\text { According to the method set Phase I, } \\
\text { Phase II, Phase III }\end{array}$ \\
\hline 24 & Drugs Free Hostels & $\begin{array}{c}\text { Hold talks / Forums / Workshops / } \\
\text { Exhibitions / Urinals }\end{array}$ \\
\hline 25 & DPEP seminar & Seminars / Forums / Workshops \\
\hline 26 & Parenting Program & $\begin{array}{c}\text { Lectures / LDK / Seminars / Forums } \\
\text { / Workshops }\end{array}$ \\
\hline 27 & DPEP's Corner, Room, Hall & Refer to MOE Circular \\
\hline 28 & Study tours & Puspen. \\
\hline 29 & $\begin{array}{c}\text { Anti-Drug Badge Scheme } \\
\text { Achievement Test }\end{array}$ & $\begin{array}{l}\text { Questions based on SLAD Log } \\
\text { Book activity }\end{array}$ \\
\hline 30 & $\begin{array}{l}\text { SLAD / DPEP Certificate } \\
\text { Given Ceremony }\end{array}$ & $\begin{array}{l}\text { Provided by DEO ( District } \\
\text { Education Office) }\end{array}$ \\
\hline
\end{tabular}


It is hoped that this planned program will be implemented in all schools and will provide awareness to all students and students about drug abuse. Education and awareness are very important to contribute to drug-free citizens and are always involved in pure value activities.

\section{ASSESSMENT AND IMPACT OF THE DPEP PROGRAM.}

The evaluation and impact of this program can be seen through the results of the annual urine test. The decrease in the number of positive students shows the effectiveness of the planned and organized implementation of DPEP. Parent/guardian and community involvement in programs related to drug abuse education are increasing. The parent/guardian begins asking questions and wants to know more about drug abuse prevention education and treatment. It is hoped that this active involvement will continue and will help the "Fight the Drugs" and "Our Responsibilities Community" program effectively. The statistics from Sungai Petai National Secondary School, (SMK SUNGAI PETAI) Pasir Puteh, Kelantan from 2013 to 2019 are as follows:

Table. 4 Urine Test Result

\begin{tabular}{|c|c|c|c|}
\hline Year & Urine Bill & Positive Bills & $\%$ \\
\hline 2013 & 30 & 1 & 3.33 \\
\hline 2014 & 36 & 0 & 0 \\
\hline 2015 & 36 & 2 & 5.55 \\
\hline 2016 & 45 & 0 & 0 \\
\hline 2017 & 16 & 5 & 31.25 \\
\hline 2018 & 47 & 4 & 8.51 \\
\hline 2019 & 22 & 0 & 0 \\
\hline
\end{tabular}

Based on the results of the urine tests made, the implementation of Drug Prevention Education (DPEP) was found to have a very positive effect on the school community. The position of Sungai Petai National School is in an area of the high risk of drug abuse but with the implementation of the Drug Prevention Education, it has been very positive.

The Drug Prevention Education Program is implemented by engaging all parties including NGOs such as Parents and Teachers Association (PTA), Sungai Petai Neighborhood Area (CRR), Pasir Puteh District Drug Recovery Committee (JKPD), Pasir Puteh Regional Anti-Drug Agency (NADA), Kelantan State NADA, Royal Malaysian Police Pasir Puteh, RELA and Pasir Puteh Fire and Rescue Department. This good collaboration has created a good rapport with all parties and has enabled the program to work well and effectively [3].

\section{SUCCESSES AND CHALLENGES IN PROGRAM SUCCESS}

The best achievement was achieved in 2019 when the school was awarded the "Anti-Drugs Exemplary School" in conjunction with the Kelantan State Level Anti-Drug Month 2019. The school was also selected as the launch site for Kelantan State Anti-Drug Day 2019 on February 19, 2019. Teacher The Sungai Petai National Secondary School DPEP was also selected as the recipient of the National Child
Superior Mentor Teacher Special Award as the Awareness Message Delivery Agent at the School Level. The award was given by the Kelantan National Anti-Drug Agency to the schools and teachers. DPEP proves that the implementation of the school's DPEP has reached the goal of establishing the DPEP hall in the school. School DPEP is also as Pasir Puteh District Drug Recovery Committee Chairman and Pasir Puteh District NADA.

The School also received the Special Award as DPEP Icon from the National Anti-Drug Agency in conjunction with the 2018 Excellent Service Award Day held on April 9, 2019. This award shows the efforts and support of teachers and the school community has been very successful in all programs related to "Our Community of Responsibility and" Fight against Drugs "being appreciated by the National Anti-Drug Agency. Implementing the Street of DPEP was the aim of achieving the goal of all students to instill the feeling of "We Hate Drugs" instead of achieving the awards. The acceptance of this award has given the school spirit and motivation to all the students to continue to receive the blessing of the DPEP Hall at this school.

DPEP lane/corner implementation has its own challenges, as implementing programs at the school. The main challenge in this successful DPEP is financial problems; no special provision has been made to purify DPEP Lane in schools. Each program is financially required to obtain materials such as paints, banners, posters, props, and other materials [4]. During the program, we also provide drinks and food to all participants. In addition, a certificate of appreciation and a certificate of participation were also given to all participants in each program in honor of the contribution and responsibility given. All programs and activities created need to be well spent. Engaging in and impacting the community also costs a lot. The understanding, determination, and commitment of all parties are very much needed as the "National No. 1 Enemy Drug" was announced on February 19, 1983, by the Honorable Prime Minister of Fourth Malaysia, Tun Dr. Mahathir Mohamad, the support of all parties is crucial to achieving the "Drug-Free School".

To overcome this challenge, schools need to implement all programs in collaboration with others such as government departments, non-governmental organizations including NGOs [5]. This collaboration will enable the school to overcome the problem of a lack of financial resources to bring and refine the DPEP hall in schools. The support of administrators, teachers, NGOs, parents, community leaders, and local communities is crucial to the successful implementation of this DPEP Lane [6]. Ongoing commitment and determination will result in exciting results.

\section{CONCLUSION}

Based on research and data collected from 2013 to 2019 at SMK Sungai Petai (Sungai Petai National Secondary School), the implementation and refinement of the Drug Prevention Education (DPEP) at this school have significantly helped reduce the number of students involved in drug abuse despite the school location. Students, parents, schoolchildren and local communities are involved in the program. Prevention education is well received by all 
participants in the program. It is hoped that this program will be able to continue successfully through the participation of all ages including kindergarten, primary school, secondary school, private and high school students, parents, and community leaders. Disclosures and dissemination of drug abuse information should be provided in any activity, whether at school, community, or religious activities. Speech and information can be conveyed in various ways through mass media, posters, brochures, and banners. Understanding and awareness of prevention are better than treating every member of society regardless of his or her educational background, social standing, and religious beliefs. Drug Prevention Education is able to and successfully provides information about the danger of drugs, drugs are our nation enemy and our community is our responsibilities.

\section{REFERENCES}

[1] Gesina L.Longenecher (1997) Cara Drug Berfungsi. Penyalahgunaan Drug Dan Tubuh Manusia. S.Abdul Majeed \& Co.

[2] Abd. Halim Mohd Hussin, Mohd Rafidi Jusoh, Lasimon Matokrem (2008) Kepulihan dan Latihan PENCEGAHAN RELAPS Dalam Penagihan Dadah, Specility Programme For Alcohol A Drug Abuse, Fakulti Kepimpinan dan Pengurusan, Universiti Sains Islam Malaysia.

[3] Julie A Hogan, Kristen Reed Gabrielsen, Nora Luna, Denise Grothaus, (2003) Substance Abuse Prevention. The Intersection of Science and Practice. University of Nevado, Reno.

[4] Kamisah Yusof, Norliza Muhammad, Nur Azlina mohd Farham, Qadriyah Hj. Mohd Saad, Ahmad Nazrun Shuid, Azman Abdullah (2009) FARMAKOLOGI pengenalan kepada farmakologi dadah. Program Diploma Siswazah Dalam Penyalahgunaan Dadah, Fakulti Kepimpinan dan Pengurusan, Universiri Sains Islam Malaysia.

[5] Mahmood Nazar Mohamed, (2006) Prevents, treats \& restores BILLING a number of approaches and practices in Malaysia.

[6] Mohd Zaidi Hajazi, (2008) Service Management Skills in Drug Abuse. Unisel Press. 